\title{
DAYA MENAHAN AIR DAN INFILTRASI PADA PERTANAMAN KEDELAI (Glycine max (L.) Merr.) DI LAHAN BPTP TEGINENENG
}

\author{
I Putu Wira Bisana, Afandi, Didin Wiharso \& Karden E. S. Manik \\ Dosen Jurusan Agroteknologi Fakultas Pertanian Universitas Lampung \\ Jl. Prof. Dr. Soemantri Brodjonegoro, No. 1 Bandar Lampung 35145
}

\begin{abstract}
ABSTRAK
Infiltrasi dan daya menahan air merupakan salah satu parameter untuk mengetahui tingkat kesuburan tanah melalui pendekatan sifat fisik tanah. Penelitian ini bertujuan untuk mengetahui pengaruh pemberian gipsum dan bahan organik terhadap laju infiltrasi dan daya menahan air pada pertanaman kedelai di lahan BPTP Tegineneng. Penelitian dilaksanakan pada bulan Agustus 2014 hingga April 2015 Lahan BPTP Unit Percobaan Tegineneng, Lampung Selatan dan Laboratorium Ilmu Tanah Fakultas Pertanian Universitas Lampung. Pada penelitian ini terdapat 4 perlakuan dan 3 ulangan. Percobaan dilakukan dengan Rancangan Acak Kelompok (RAK), dan ntuk infiltrasi penelitian ini menggunakan metode singgel ring. Laju infiltrasi paling cepat pada irigasi 0,5 (penyiraman 3 hari sekali) terdapat pada perlakuan $\mathrm{G}_{1}$ (gipsum $130 \mathrm{~kg} / \mathrm{ha}$ ) dengan kecepatan laju infiltrasi awal (5 menit ke 1) $324 \mathrm{~mm} / \mathrm{jam}$ dan titik konstan (5 menit ke 5) 168 19,60 km/jam sedangkan pada irigasi 0,75 (penyiraman 6 hari sekali) terdapat pada perlakuan $B_{1}$ (bahan organik 5 ton/ha) dengan laju infiltrasi awal (5 menit ke 1) $200 \mathrm{~mm} /$ jam dan laju infiltrasi konstan (5 menit ke 5) $72 \mathrm{~mm} / \mathrm{jam}$. Penambahan bahan organik pada penelitian ini meningkatkan daya menahan air tanah.
\end{abstract}

Kata kunci : Daya menahan air, Infiltrasi, Kerapatan isi, Porositas, Tanaman Kedelai

\section{PENDAHULUAN}

Kedelai (Glycine max (L.) Merr.) merupakan tanaman pangan yang penting sebagai sumber protein nabati. BPS 2014 melaporkan bahwa produksi kedelai tahun 2014 diperkirakan sebesar 892,60 ribu ton biji kering atau meningkat sebesar 14,44 persen dibanding tahun 2013. Pada lahan percobaan BPTP Tegineneng yang digunakan untuk penelitian ini tanahnya berjenis ultisol yang dimana tanah Ultisol merupakan salah satu jenis tanah di Indonesia yang mempunyai sebaran luas, mencapai 45.794 .000 ha atau sekitar 25\% dari total luas daratan Indonesia (Subagyo, dkk,2000). Peningkatan produktivitas tanah ultisol dapat dilakukan melalui perbaikan tanah seperti pemupukan, pemberian bahan organik bahkan juga dengan aplikasi gipsum.

Bahan organik bertujuan untuk meningkatkan kesuburan tanah secara fisik, kimia maupun biologis karena bahan organik memiliki kandungan unsur hara seperti $\mathrm{N}, \mathrm{P}, \mathrm{K}, \mathrm{Ca}, \mathrm{Mg}$ dan unsur hara mikro lainnya. Selain pemberian bahan organik, aplikasi gipsum juga mampu memperbaiki sifat fisik dan kimia tanah, seperti KTK, kapasitas menahan air (Nelson, 1997), meningkatkan kandungan $\mathrm{Ca}$ dan $\mathrm{S}$ yang merupakan unsur essensial tanaman dan sebagai pemantap tanah
(Hoeft, 2001).

Infiltrasi dan daya menahan air merupakan salah satu parameter yang dapat menunjukan perbedaan perlakuan bahan organik dan gipsum yang akan diaplikasikan. Infiltrasi merupakan peristiwa atau proses masuknya air ke dalam tanah, umumnya (tetapi tidak mesti) melalui permukaan tanah dan secara vertikal. Penigkatan laju infiltrasi berbanding lurus dengan peningkatan daya menahan air. Pemberian bahan organik dan gipsum diharapkan dapat meningkatkan laju infiltrasi dan daya menahan air tersebut. Adapun tujuan dari penelitian ini adalah untuk: (1) Mengetahui pengaruh pemberian gipsum dan bahan organik terhadap laju infiltrasi; (2) Mengetahui pengaruh pemberian gipsum dan bahan organik terhadap daya menahan air tanah.

\section{METODE PENELITIAN}

Penelitian ini dilaksanakan di Lahan BPTP Unit Percobaan Tegineneng, Lampung Selatan dan Laboratorium Ilmu Tanah Fakultas Pertanian Universitas Lampung. Waktu pelaksanaan pada Agustus 2014 hingga April 2015. Bahan yang digunakan dalam percobaan ini adalah pupuk dasar, gipsum, bahan organik, benih kedelai varietas Tanggamus dan air. Alat 
yang digunakan dalam penelitian ini terdiri dari alat pengolah, palu, infiltrometer, ring sample, penggaris, ember, plastik, dan kertas label.

Penelitian ini menggunakan Rancangan Acak Kelompok (RAK) menggunakan kedelai varietas Tanggamus dengan 4 perlakuan yaitu:

1. $\mathrm{B}_{0}$ : Kontrol atau tanpa bahan organik

2. $B_{1}$ : Dengan bahan organik dosis 5 ton $/ \mathrm{Ha}$ (2kg/petak)

3. $\mathrm{B}_{2}$ : Aaplikasi bahan organik $10 \mathrm{ton} / \mathrm{ha}(4 \mathrm{~kg} /$ petak)

4. $\mathrm{G}_{1}$ : Dengan pemberian Gipsum dosis $130 \mathrm{~kg} / \mathrm{ha}$

Kombinasi perlakuan berjumlah 4 dan diulang 3 kali pada irigasi 0,5 (penyiraman 3 hari sekali / 50\% field capacity) dan 0,75 (penyiraman 6 hari sekali / 75\% field capacity) maka diperoleh 24 satuan percobaan.

Persiapan lahan dilakukan dengan pembajakan menggunakan traktor, lahan dibagi menjadi 12 petak percobaan dengan ukuran $2 \mathrm{~m}$ X $2 \mathrm{~m}$. Aplikasi setiap perlakuan baik bahan organik maupun gipsum dilakukan pada saat pengolahan lahan. Lahan yang telah diolah ditanami kedelai dengan jarak tanam $20 \mathrm{~cm} \mathrm{X} 20 \mathrm{~cm}$. Dalam setiap petak percobaan terdapat 50 lubang tanaman dan 10 tanaman ditentukan sebagai sampel yang dipilih secara acak. setelah itu dilakukan penyiraman hingga mengalami titik jenuh atau \pm 40 liter/ petak $\left(4 \mathrm{~m}^{2}\right)$.

Pupuk yang digunakan ialah Urea, SP36, $\mathrm{KCl}$ dengan dosis yang telah ditentukan yaitu dengan perbandingan pupuk Urea : $\mathrm{SP} 36: \mathrm{KCl}$ sebanyak $1 \mathrm{~kg}$ : $2 \mathrm{~kg}: 1 \mathrm{~kg}$ atau setara dengan $250 \mathrm{~kg} / \mathrm{ha}: 500 \mathrm{~kg} / \mathrm{ha}$ : $250 \mathrm{~kg} / \mathrm{ha}$ ). Pemupukan dilakukan sebanyak 2 kali, yaitu pada saat tanaman berumur 15 hari dan saat menjelang pembungaan. Untuk analisis daya menahan air pengambilan sample tanah dilakukan setelah panen dengan menggunakan ring sample dan untuk unfiltrasi dilakukan dilahan langsung dengan menggunakan metode singgle ring infiltrometer. Variabel yang di amati dalam penelitian ini adalah Laju infiltrasi, daya menahan air.

\section{HASIL DAN PEMBAHASAN}

Pengukuran laju infiltrasi menggunakan metode single ring infiltrometer dan di ulang sebanyak 5 kali pengukuran dilaksanakan selama 5 menit sampai mendapatkan hasil yang konstan, maka akumulai waktu pengukuran selama 25 menit. Tabel 1 merupakan penetapan kriteria dari pengukuran laju infiltrasi konstan menurut Haridjaja, (1990). Yang digunakan untuk menentukan laju infiltrasi dari penelitian ini. Dari hasil pengamatan yang dilakukan didapatkan laju infiltrasi sebagai berikut.

Berdasarkan pengamatan yang tersaji pada tabel
Tabel 1. Kriteria Laju Infiltrasi Konstan

\begin{tabular}{clcl}
\hline Kelas & $\begin{array}{c}\text { Kategori } \\
\text { Infiltrasi }\end{array}$ & $\begin{array}{c}\text { Laju } \\
\text { Infiltrasi } \\
\text { Konstan } \\
(\mathbf{m m} \text { /jam) }\end{array}$ & Keterangan \\
\hline 1 & Sangat Lambat & $<1$ & Non Irigasi \\
2 & Lambat & $1-5$ & \\
3 & Agak Lambat & $5-20$ & \\
4 & Sedang & $20-60$ & \\
5 & Agak Cepat & $60-125$ & \\
6 & Cepat & $125-250$ & Perlakuan Khusus \\
7 & Sangat Cepat & $>250$ & \\
\hline \multicolumn{4}{l}{ (Sumber: Haridjaja, 1990) }
\end{tabular}

2 menunjukan bahwa kecepatan laju infiltrasi agak cepat menurut kriteria dari Haridjaja, (1990) dengan nilai laju infiltrasi awal (5 menit ke 1) $308 \mathrm{~mm} / \mathrm{jam}$ dan nilai laju infiltrasi konstan (5 menit ke 5) $96 \mathrm{~mm} / \mathrm{jam}$. Berdasarkan pengamatan yang tersaji pada tabel 3 menunjukan bahwa kecepatan laju infiltrasi agak cepat menurut kriteria dari Haridjaja, (1990) dengan nilai laju infiltrasi awal (5 menit ke 1) $172 \mathrm{~mm} / \mathrm{jam}$ dan nilai laju infiltrasi konstan (5 menit ke 5) $80 \mathrm{~mm} / \mathrm{jam}$. Berdasarkan pengamatan yang tersaji pada tabel 4 menunjukan bahwa kecepatan laju infiltrasi agak cepat menurut kriteria dari Haridjaja, (1990) dengan nilai laju infiltrasi awal (5 menit ke 1) $168 \mathrm{~mm} /$ jam dan nilai laju infiltrasi konstan (5 menit ke 5) 60 $\mathrm{mm} / \mathrm{jam}$. Berdasarkan pengamatan yang tersaji pada tabel 5 menunjukan bahwa kecepatan laju infiltrasi cepat

Tabel 2. Pengaruh aplikasi bahan pembenah tanah terhadap laju infiltrasi lahan tanaman kedelai untuk irigasi 3 hari sekali pada perlakuan $\mathrm{B}_{0}$ (kontrol)

\begin{tabular}{|c|c|c|c|c|c|}
\hline Waktu & $\begin{array}{c}\text { Akumulasi } \\
\text { Waktu } \\
\text { (Menit) }\end{array}$ & $\mathbf{C m}$ & $\begin{array}{c}\mathrm{cm} / \\
\text { menit }\end{array}$ & $\begin{array}{l}\mathrm{cm} / \\
\text { jam }\end{array}$ & $\begin{array}{c}\mathbf{m m} / \\
\text { jam }\end{array}$ \\
\hline 5 Menit '1 & 5 & 2,57 & 0,51 & 30,8 & 308 \\
\hline 5 Menit '2 & 10 & 2,03 & 0,41 & 24,4 & 244 \\
\hline 5 Menit '3 & 15 & 1,53 & 0,31 & 18,4 & 184 \\
\hline 5 Menit ' 4 & 20 & 1,23 & 0,25 & 14,8 & 148 \\
\hline 5 Menit '5 & 25 & 0,80 & 0,16 & 9,6 & 96 \\
\hline
\end{tabular}

Tabel 3. Pengaruh aplikasi bahan pembenah tanah terhadap laju infiltrasi lahan tanaman kedelai untuk irigasi 3hari sekali pada perlakuan $\mathrm{B}_{1}$ (bahan organik 5 ton/ha)

\begin{tabular}{|c|c|c|c|c|c|}
\hline Waktu & $\begin{array}{c}\text { Akumulasi } \\
\text { Waktu } \\
\text { (Menit) }\end{array}$ & $\mathrm{Cm}$ & $\underset{\text { menit }}{\mathrm{cm} /}$ & $\begin{array}{l}\mathrm{cm} / \\
\text { jam }\end{array}$ & $\begin{array}{l}\text { mm/ } \\
\text { jam }\end{array}$ \\
\hline 5 Menit '1 & 5 & 1,43 & 0,29 & 17,2 & 172 \\
\hline 5 Menit '2 & 10 & 1,23 & 0,25 & 14,8 & 148 \\
\hline 5 Menit '3 & 15 & 1,03 & 0,21 & 12,4 & 124 \\
\hline 5 Menit '4 & 20 & 0,77 & 0,15 & 9,2 & 92 \\
\hline 5 Menit '5 & 25 & 0,67 & 0,13 & 8 & 80 \\
\hline
\end{tabular}


Tabel 4. Pengaruh aplikasi bahan pembenah tanah terhadap laju infiltrasi lahan tanaman kedelai untuk irigasi 3 hari sekali pada perlakuan $\mathrm{B}_{2}$ (bahan organik 10 ton/ha)

\begin{tabular}{lccccc}
\hline Waktu & $\begin{array}{c}\text { Akumulasi } \\
\text { Waktu } \\
\text { (Menit) }\end{array}$ & Cm & $\begin{array}{c}\text { cm/ } \\
\text { menit }\end{array}$ & $\begin{array}{c}\text { cm/ } \\
\text { jam }\end{array}$ & $\begin{array}{c}\text { mm/ } \\
\text { jam }\end{array}$ \\
\hline 5 Menit '1 & 5 & 1,40 & 0,28 & 16,8 & 168 \\
5 Menit '2 & 10 & 0,97 & 0,19 & 11,6 & 116 \\
5 Menit '3 & 15 & 0,73 & 0,15 & 8,8 & 88 \\
5 Menit '4 & 20 & 0,57 & 0,11 & 6,8 & 68 \\
5 Menit '5 & 25 & 0,50 & 0,10 & 6 & 60 \\
\hline
\end{tabular}

menurut kriteria dari Haridjaja, (1990) dengan nilai laju infiltrasi awal (5 menit ke 1) $324 \mathrm{~mm} / \mathrm{jam}$ dan nilai laju infiltrasi konstan (5 menit ke 5) $168 \mathrm{~mm} / \mathrm{jam}$.

Berdasarkan pengamatan yang tersaji pada tabel 6 menunjukan bahwa kecepatan laju infiltrasi agak cepat menurut kriteria dari Haridjaja, (1990) dengan nilai laju infiltrasi awal (5 menit ke 1) $200 \mathrm{~mm} / \mathrm{jam}$ dan nilai laju infiltrasi konstan (5 menit ke 5) $72 \mathrm{~mm} / \mathrm{jam}$. Berdasarkan pengamatan yang tersaji pada tabel 7 menunjukan bahwa kecepatan laju infiltrasi cepat menurut kriteria dari Haridjaja, (1990) dengan nilai laju infiltrasi awal (5 menit ke 1) $364 \mathrm{~mm} / \mathrm{jam}$ dan nilai laju infiltrasi konstan (5 menit ke 5) $196 \mathrm{~mm} / \mathrm{jam}$. Berdasarkan pengamatan yang tersaji pada tabel 8 di atas menunjukan bahwa

Tabel 6. Pengaruh aplikasi bahan pembenah tanah terhadap laju infiltrasi lahan tanaman kedelai untuk irigasi 0,75 (6 hari sekali) pada perlakuan $\mathrm{B}_{0}$ (kontrol)

\begin{tabular}{lccccc}
\hline Waktu & $\begin{array}{c}\text { Akumulasi } \\
\text { Waktu } \\
\text { (Menit) }\end{array}$ & Cm & $\begin{array}{c}\text { cm/ } \\
\text { menit }\end{array}$ & $\begin{array}{c}\text { cm/ } \\
\text { jam }\end{array}$ & $\begin{array}{c}\text { mm/ } \\
\text { jam }\end{array}$ \\
\hline 5 Menit'1 & 5 & 1,67 & 0,33 & 20 & 200 \\
5 Menit '2 & 10 & 1,10 & 0,22 & 13,2 & 132 \\
5 Menit '3 & 15 & 0,80 & 0,16 & 9,6 & 96 \\
5 Menit'4 & 20 & 0,60 & 0,12 & 7,2 & 72 \\
5 Menit'5 & 25 & 0,60 & 0,12 & 7,2 & 72 \\
\hline
\end{tabular}

Tabel 8. Pengaruh aplikasi bahan pembenah tanah terhadap laju infiltrasi lahan tanaman kedelai untuk irigasi 0,75 (6 hari sekali) pada perlakuan $\mathrm{B}_{2}$ (bahan organik 10 ton/ha)

\begin{tabular}{lccccc}
\hline Waktu & $\begin{array}{c}\text { Akumulasi } \\
\text { Waktu } \\
\text { (Menit) }\end{array}$ & Cm & $\begin{array}{c}\text { cm/ } \\
\text { menit }\end{array}$ & $\begin{array}{c}\text { cm/ } \\
\text { jam }\end{array}$ & $\begin{array}{c}\text { mm/ } \\
\text { jam }\end{array}$ \\
\hline 5 Menit'1 & 5 & 2,10 & 0,42 & 25,2 & 252 \\
5 Menit '2 & 10 & 1,77 & 0,35 & 21,2 & 212 \\
5 Menit '3 & 15 & 1,60 & 0,32 & 19,2 & 192 \\
5 Menit'4 & 20 & 1,67 & 0,33 & 20 & 200 \\
5 Menit '5 & 25 & 1,30 & 0,26 & 15,6 & 156 \\
\hline
\end{tabular}

Tabel 5. Pengaruh aplikasi bahan pembenah tanah terhadap laju infiltrasi lahan tanaman kedelai untuk irigasi 3 hari sekali pada perlakuan $\mathrm{G}_{1}$ (gipsum $130 \mathrm{~kg} / \mathrm{ha}$ )

\begin{tabular}{lccccc}
\hline Waktu & $\begin{array}{c}\text { Akumulasi } \\
\text { Waktu } \\
\text { (Menit) }\end{array}$ & Cm & $\begin{array}{c}\text { cm/ } \\
\text { menit }\end{array}$ & $\begin{array}{c}\text { cm/ } \\
\text { jam }\end{array}$ & $\begin{array}{c}\text { mm/ } \\
\text { jam }\end{array}$ \\
\hline 5 Menit'1 & 5 & 2,70 & 0,54 & 32,4 & 324 \\
5 Menit '2 & 10 & 2,43 & 0,49 & 29,2 & 292 \\
5 Menit'3 & 15 & 1,93 & 0,39 & 23,2 & 232 \\
5 Menit '4 & 20 & 1,63 & 0,33 & 19,6 & 196 \\
5 Menit '5 & 25 & 1,40 & 0,28 & 16,8 & 168 \\
\hline
\end{tabular}

kecepatan laju infiltrasi cepat menurut kriteria dari Haridjaja, (1990) dengan nilai laju infiltrasi awal (5 menit ke 1) $252 \mathrm{~mm} / \mathrm{jam}$ dan nilai laju infiltrasi konstan (5 menit ke 5) $156 \mathrm{~mm} / \mathrm{jam}$. Berdasarkan pengamatan yang tersaji pada tabel 9 di atas menunjukan bahwa kecepatan laju infiltrasi cepat menurut kriteria dari Haridjaja, (1990) dengan nilai laju infiltrasi awal (5 menit ke 1) $292 \mathrm{~mm} / \mathrm{jam}$ dan nilai laju infiltrasi konstan (5 menit ke 5) $160 \mathrm{~mm} / \mathrm{jam}$.

\section{Kerapatan isi, porositas dan kadar air tanah}

Banyak faktor yang mempengaruhi laju infitrasi, diantaranya adalah kerapatan isi, porositas dan kadar air tanah. Berdasarkan hasil pengamatan didapatkan

Tabel 7. Pengaruh aplikasi bahan pembenah tanah terhadap laju infiltrasi lahan tanaman kedelai untuk irigasi 0,75 (6 hari sekali) pada perlakuan $\mathrm{B}_{1}$ (bahan organik 5 ton/ha)

\begin{tabular}{lccccc}
\hline Waktu & $\begin{array}{c}\text { Akumulasi } \\
\text { Waktu } \\
\text { (Menit) }\end{array}$ & Cm & $\begin{array}{c}\text { cm/ } \\
\text { menit }\end{array}$ & $\begin{array}{c}\text { cm/ } \\
\text { jam }\end{array}$ & $\begin{array}{c}\text { mm/ } \\
\text { jam }\end{array}$ \\
\hline 5 Menit '1 & 5 & 3,03 & 0,61 & 36,4 & 364 \\
5 Menit '2 & 10 & 2,27 & 0,45 & 27,2 & 272 \\
5 Menit '3 & 15 & 2,07 & 0,41 & 24,8 & 248 \\
5 Menit '4 & 20 & 1,70 & 0,34 & 20,4 & 204 \\
5 Menit '5 & 25 & 1,63 & 0,33 & 19,6 & 196 \\
\hline
\end{tabular}

Tabel 9. Pengaruh aplikasi bahan pembenah tanah terhadap laju infiltrasi lahan tanaman kedelai untuk irigasi 0,75 (6 hari sekali) pada perlakuan $\mathrm{G}_{1}$ (gipsum $130 \mathrm{~kg} / \mathrm{ha})$

\begin{tabular}{|c|c|c|c|c|c|}
\hline Waktu & $\begin{array}{c}\text { Akumulasi } \\
\text { Waktu } \\
\text { (Menit) }\end{array}$ & $\mathrm{Cm}$ & $\begin{array}{c}\mathrm{cm} / \\
\text { menit }\end{array}$ & $\begin{array}{l}\mathrm{cm} / \\
\text { jam }\end{array}$ & $\begin{array}{c}\text { mm/ } \\
\text { jam }\end{array}$ \\
\hline 5 Menit ' 1 & 5 & 2,43 & 0,49 & 29,2 & 292 \\
\hline 5 Menit '2 & 10 & 1,83 & 0,37 & 22 & 220 \\
\hline 5 Menit ‘3 & 15 & 1,50 & 0,30 & 18 & 180 \\
\hline 5 Menit ‘ 4 & 20 & 1,33 & 0,27 & 16 & 160 \\
\hline 5 Menit ‘5 & 25 & 1,33 & 0,27 & 16 & 160 \\
\hline
\end{tabular}


hasil sebagai berikut :

Berdasarkan grafik 1 pengaruh aplikasi bahan pembenah tanah terhadap berat basah tanah $(\mathrm{pF} 0)$ pada pertanaman kedelai untuk irigasi 0,5 berat basah tertinggi terdapat pada perlakuan $\mathrm{G}_{1}$ (gipsum $130 \mathrm{~kg} / \mathrm{ha}$ ) yaitu sebesar 138,76 $\mathrm{g}$ dan berat basah terendah terdapat pada perlakuan $\mathrm{B}_{0}$ (kontrol) yaitu sebesar $129,74 \mathrm{~g}$. Sedangkan untuk irigasi 0,75 berat basah tanah tertinggi terdapat pada perlakuan $\mathrm{B}_{2}$ (bahan organik 10 ton/ha) yaitu sebesar 129,53 g, dan yang terendah terdapat pada perlakuan $\mathrm{B}_{0}$ (kontrol) yaitu sebesar 125,88 g.

Berdasarkan tabel 10 pengaruh aplikasi bahan pembenah tanah pada pertanaman kedelai terhadap persentase Kadar air tanah untuk irigasi 0,5 hasil tertinggi pada $\mathrm{pF} 2,54$ terdapat pada perlalakuan $\mathrm{B}_{1}$ (bahan organik 5 ton/ha) yaitu sebesar $43,75 \%$, sedangkan persentase hasil terendah terdapat pada perlakuan $\mathrm{G}_{1}$ (gipsum $130 \mathrm{~kg} / \mathrm{ha}$ ) yaitu sebesar $36,74 \%$. Untuk irigasi $0,5 \mathrm{pF} 4,4$ persentase kadar air tertinggi terdapat pada perlakuan $\mathrm{G}_{1}$ (gypsum $130 \mathrm{~kg} / \mathrm{ha}$ ) yaitu sebesar $30,21 \%$ dan yang terendah terdapat pada perlakuan $\mathrm{B}_{1}$ (bahan organik 5 ton/ha) sebesar 24,09\%. Di samping itu pada irigasi $0,75 \mathrm{pF} 2,54$ persentase kadar air tertinggi terdapat pada perlakuan $\mathrm{G}_{1}$ (gipsum 130 ton/ha) yaitu sebesar $35,03 \%$ dan yang terendah terdapat pada perlakuan $\mathrm{B}_{0}$ (kontrol) yaitu sebesar $33,03 \%$. Sedangkan $0,75 \mathrm{pF} 4,4$ persentase kadar air tertinggi terdapat pada perlakuan $\mathrm{G}_{1}$ (gipsum $130 \mathrm{~kg} / \mathrm{ha}$ ) yaitu sebesar $27,35 \%$ dan yang terendah terdapat pada perlakuan $\mathrm{B}_{1}$ (bahan organik 5 ton/ha) yaitu sebesar 21,18.

Berdasarkan grafik 2 pengaruh aplikasi bahan pembenah tanah pada pertanaman kedelai terhadap kerapatan isi untuk hasil tertinggi pada irigasi 0,5 terdapat

Tabel 10. Pengaruh aplikasi bahan pembenah tanah terhadap kadar air tanah lahan tanaman kedelai $(\%)$.

\begin{tabular}{ccccc}
\hline \multirow{2}{*}{ Perlakuan } & \multicolumn{2}{c}{ Irigasi 0,5} & \multicolumn{2}{c}{ Irigasi 0,75} \\
\cline { 2 - 5 } & $\mathrm{pF} 2,54$ & $\mathrm{pF} 4,4$ & $\mathrm{pF} 2,54$ & $\mathrm{pF} 4,4$ \\
\hline $\mathrm{B}_{0}$ & 38,77 & 29,52 & 33,03 & 27,33 \\
$\mathrm{~B}_{1}$ & 43,75 & 24,09 & 33,66 & 21,18 \\
$\mathrm{~B}_{2}$ & 37,50 & 28,54 & 34,77 & 22,90 \\
$\mathrm{G}_{1}$ & 36,74 & 30,21 & 35,03 & 27,35 \\
\hline
\end{tabular}

Keterangan : kontrol atau tanpa bahan organik $\left(\mathrm{B}_{0}\right)$, bahan organik 5 ton/ha $\left(\mathrm{B}_{1}\right)$, bahan organik 10 ton/ ha $\left(\mathrm{B}_{2}\right)$ dan gipsum $130 \mathrm{~kg} / \mathrm{ha}\left(\mathrm{G}_{1}\right)$. pada perlakuan $\mathrm{G}_{1}$ (gipsum $130 \mathrm{~kg} / \mathrm{ha}$ ) yaitu sebesar $1,28 \%$ dan hasil terendah terdapat pada perlakuan $\mathrm{B}_{0}$ (kontrol) yaitu sebesar $1,17 \%$. Sedangkan persentase tertinggi kerapatan isi pada irigasi 0,75 terdapat pada perlakuan $B_{1}$ (bahan organik 5 ton/ha) yaitu sebesar $1,20 \%$, dan persentase terendah terdapat pada perlakuan $\mathrm{B}_{0}$ (kontrol) yaitru sebesar $1,17 \%$.

Berdasarkan grafik 3 pengaruh aplikasi bahan pembenah tanah pada pertanaman kedelai terhadap porositas tanah untuk hasil tertinggi pada irigasi 0,5 terdapat pada perlakuan $\mathrm{B}_{1}$ ( bahan organik 5 ton/ha) yaitu sebesar $56 \%$ dan hasil terendah terdapat pada perlakuan $\mathrm{G}_{1}$ (gipsum $130 \mathrm{~kg} / \mathrm{ha}$ ) yaitu $51 \%$. Sedangkan persentase porositas tanah pada irigasi 0,75 hasil tertinggi terdapat pada perlakuan $\mathrm{B}_{0}$ (kontrol) yaitu sebesar 56 $\%$, dan persentase porositas terendah terdapat pada perlakuan $\mathrm{B}_{1}$ (bahan organik 5 ton/ha) yaitu sebesar 54 $\%$.

Berdasarkan grafik 4 pengaruh bahan pembenah tanah pada pertanaman kedelai persentase air tersedia untuk hasil tertinggi pada irigasi 0,5 terletak pada perlakuan $\mathrm{B}_{1}$ (bahan organik 5 ton/ha) yaitu 19,66\% dan hasil terendah terdapat pada perlakuan $\mathrm{G}_{1}$ (gipsum $130 \mathrm{~kg} / \mathrm{ha}$ ) yaitu sebesar $6,53 \%$. Sedangkan pada irigasi 0,75 persentase air tersedia tertinggi terdapat pada perlakuan $\mathrm{B}_{1}$ (bahan organik 5 ton/ha) yaitu sebesar $12,48 \%$, dan hasil terendah terdapat pada perlakuan $\mathrm{B}_{0}$ (kontrol) yaitu sebesar \% .

\section{Pembahasan}

Infiltrasi sangat mempengaruhi ketersediaan sumber daya air dalam tanah. Banyaknya air per satuan waktu yang masuk melalui permukaan tanah disebut laju

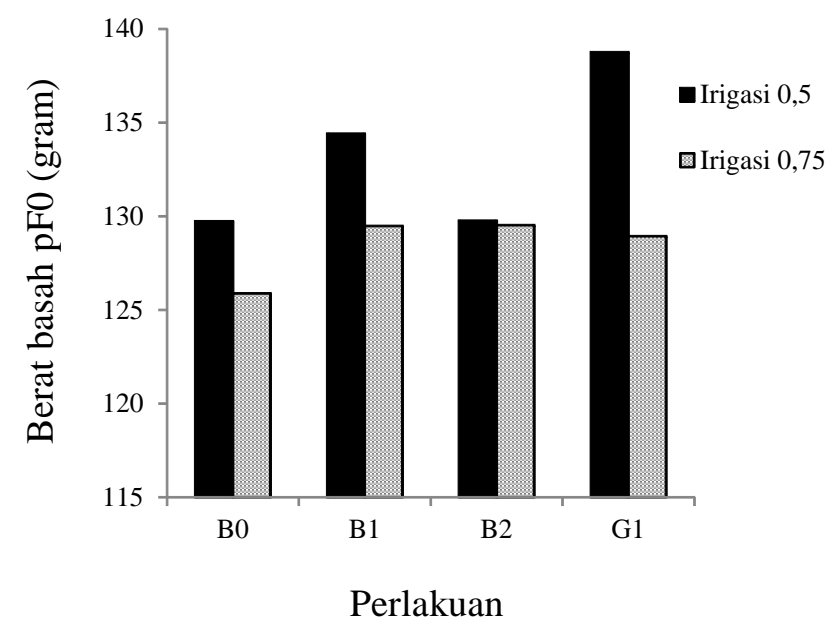

Grafik 1. Pengaruh aplikasi bahan pembenah tanah terhadap berat tanah basah $(\mathrm{pF} 0)$ irigasi 0,5 dan irigasi 0,75 


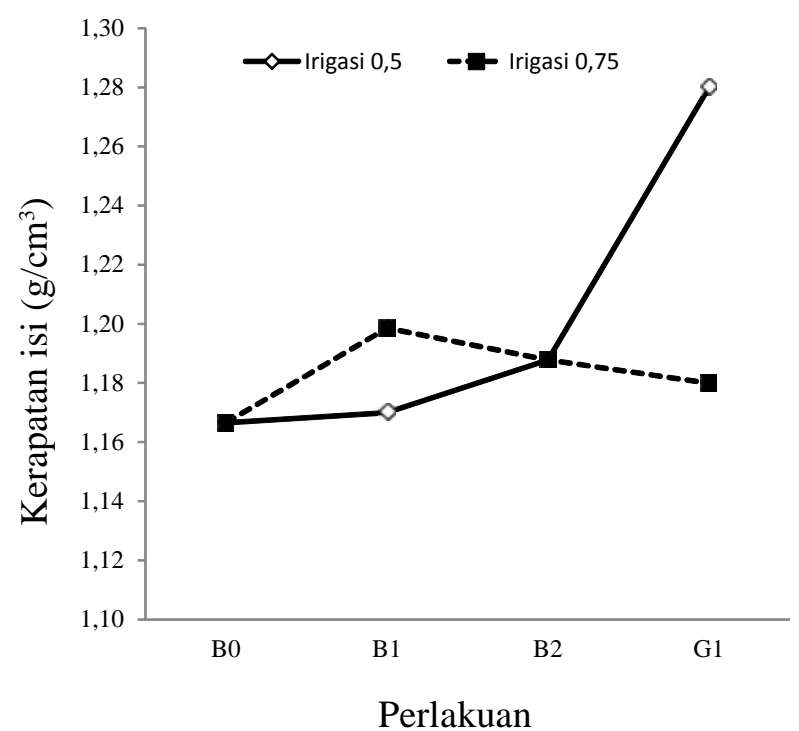

Grafik 2. Pengaruh aplikasi bahan pembenah tanah terhadap kerapatan isi lahan tanaman kedelai $\left(\mathrm{g} / \mathrm{cm}^{3}\right)$

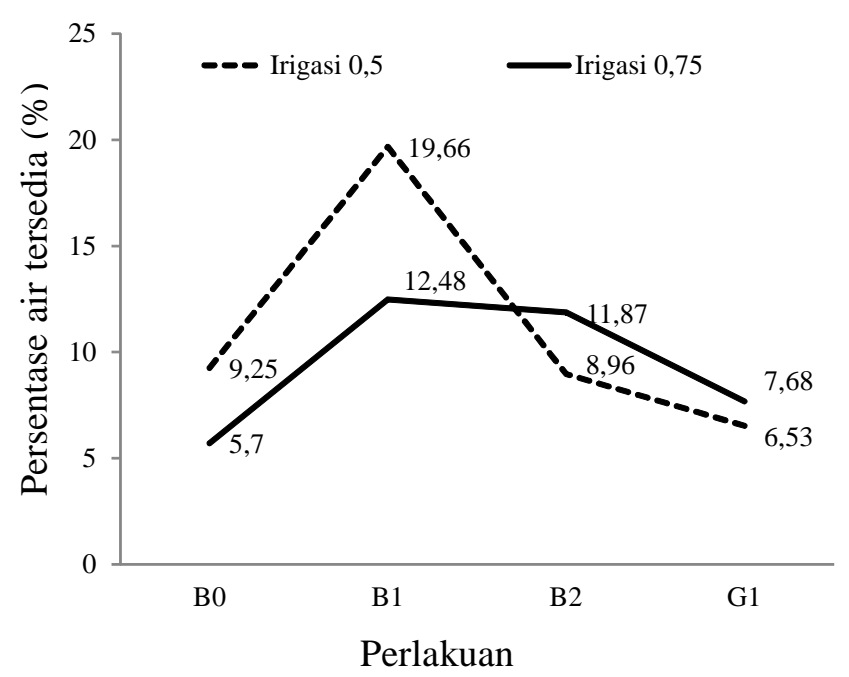

Grafik 4. Pengaruh aplikasi bahan pembenah tanah terhadap persentase air tersedia pada pertanaman kedelai

infiltrasi (infiltration rate). Laju infiltrasi untuk irigasi 0,5 ( penyiraman 3 hari sekali) paling lambat terdapat pada perlakuan $B_{2}$ (bahan organik 10 ton/ha) $168 \mathrm{~mm} /$ jam pada kecepatan awal dan $60 \mathrm{~mm} / \mathrm{jam}$ pada titik konstan, menurut kriteria laju infiltrasi konstan oleh Haridjaja (1990) laju konstan pada perlakuan ini masuk dalam kategori agak cepat. Sedangkan laju infiltrasi paling cepat pada irigasi 0,5 (penyiraman 3 hari sekali) terdapat pada perlakuan $\mathrm{G}_{1}$ (gipsum $130 \mathrm{~kg} / \mathrm{ha}$ ) dengan kecepatan awal (5 menit ke 1) $324 \mathrm{~mm} / \mathrm{jam}$ dan titik konstan (5 menit ke 5) $168 \mathrm{~mm} /$ jam maka sesuai dengan

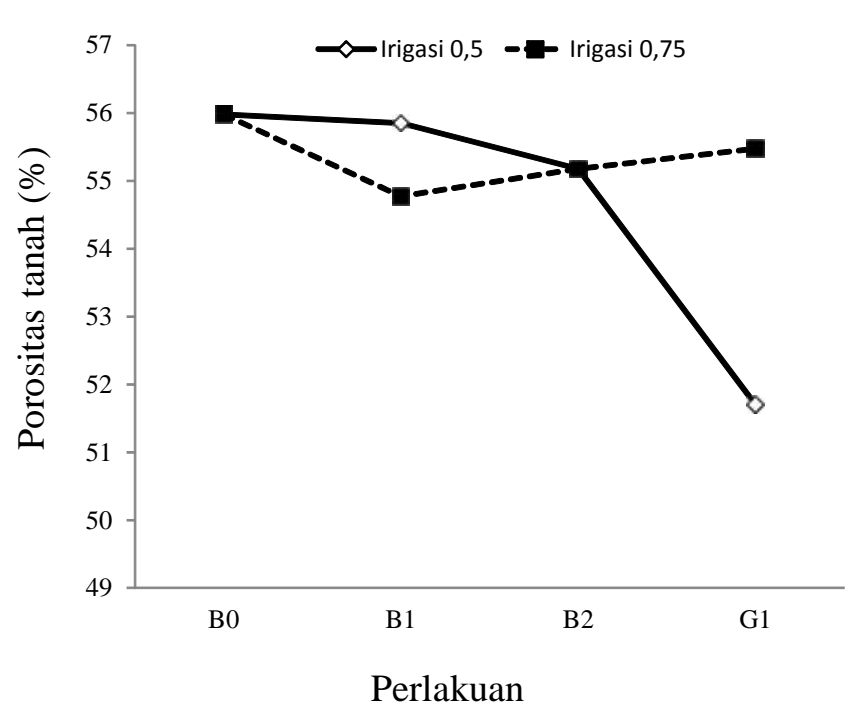

Grafik 3. Pengaruh aplikasi bahan pembenah tanah terhadap porositas tanah lahan tanaman kedelai $(\%)$

kriteria laju infiltrasi konstan oleh Haridjaja (1990) masuk dalam kategori cepat. Hal ini membuktikan bahwa pemberian bahan pembenah tanah (gipsum $130 \mathrm{~kg} / \mathrm{ha}$ ) dapat meningkatkan laju infiltrasi tanah dibandingkan dengan tanpa pemberian perlakuan atau kontrol dan pemberian perlakuan bahan organik 10 ton/ha (perlakuan $\mathrm{B}_{2}$ ) atau pada perlakuan $\mathrm{B}_{1}$ (bahan organik 5 ton/ha) dapat menurunkan laju infiltrasi karena bahan organik yang terdapat dalam tanah mampu menahan laju infiltrasi tanah. Sesuai dengan Kurniawan, dkk (2014) yang menyatakan bahwa, gipsum dapat meningkatkan stabilitas tanah karena mengandung kalsium yang mengikat tanah serta mampu meningkatkan agregat dan ruang pori tanah. Selain itu gipsum juga dapat meningkatkan kecepatan rembesan air, dikarenakan gipsum lebih menyerap banyak air.

Disamping itu, untuk irigasi 0,75( penyiraman 6 hari sekali) laju infiltrasi paling lambat terdapat pada perlakuan $\mathrm{B}_{0}$ (kontrol) dengan laju kecepatan awal (5 menit ke 1) $200 \mathrm{~mm} / \mathrm{jam}$ dan laju infiltrasi konstan (5 menit ke 5) $72 \mathrm{~mm} / \mathrm{jam}$, menurut kriteria laju infiltrasi konstan oleh Haridjaja (1990) laju konstan pada perlakuan ini masuk dalam kategori agak cepat. Dan laju infiltrasi paling cepat pada irigasi 0,75 (penyiraman 6 hari sekali) terdapat pada perlakuan $B_{1}$ (bahan organik 5 ton/ha) dengan laju infiltrasi awal (5 menit ke 1) 364 mm/jam dan laju infiltrasi konstan (5 menit ke 5) 196 $\mathrm{mm} / \mathrm{jam}$, menurut kriteria laju infiltrasi konstan oleh Haridjaja (1990) laju konstan pada perlakuan ini masuk dalam kategori cepat. Hal ini menunjukan irigasi/ 
penyiraman dapat mempengaruhi laju ilfiltasi tanah yang mana pada perlakuan irigasi 0,5 laju infiltasi paling cepat pada perlakuan $\mathrm{G}_{1}$ (gipsum $130 \mathrm{~kg} / \mathrm{ha}$ sedangkan pada irigasi 0,75 terdapat pada perlakuan $\mathrm{B}_{1}$ (bahan organik 5 ton/ha). Sesuai dengan Atmojo, S.W., (2003) yang menyatakan bahwa bahan organik berperan penting dalam meningkatkan kualitas fisik tanah, dalam hal ini dapat memperbaiki struktur tanah melalui agregasi dan aerasi tanah sehingga laju infiltrasi dapat lebih cepat.

Menurut Arsyad (2006) laju Infiltrasi dapat diperbesar dengan mempengaruhi salah satu dari faktorfaktor yang mempengaruhi laju infiltrasi yaitu, meningkatkan banyaknya air yang masuk kedalam tanah, pembuatan galengan atau pengolahan lahan menurut kontur, dengan pemberian mulsa, pemupukan dengan pupuk organik, penutupan tanah dengan vegetasi atau sisa-sisa tanaman dan menjaga ekosistem flora dalam tanah karena lubang atau celah-celah pada tanah yang ditimbulkan oleh binatang-binatang tanah, seperti cacing dan serangga dapat memperbesar jumlah air yang meresap kedalam tanah.

Kadar air tanah tertinggi pada penelitian ini untuk irigasi 0,5 pada $\mathrm{pF} 2,54$ terdapat pada perlakuan $\mathrm{B}_{1}$ sedangkan pada irigasi 0,75 terdapat pada perlakuan $\mathrm{G}_{1}$. Pada irigasi $0,5 \mathrm{pF} 4,4$ kadar air tanah tertinggi terdapat pada perlakuan $\mathrm{G}_{1}$, sedangkan pada irigasi 0,75 terdapat pada perlakuan $\mathrm{B}_{1}$ (Tabel 10). Hal ini dapar disebabkan banyaknya air yang terserap tanaman dan yang terdapat dilahan berbeda-beda selain itu perlakuan yang diterapkan juga curah hujan mempengaruhi keadaan kadar air pada tanah.

Berdasarkan pengamatan dan uji laboratorium yang telah dilakukan pada penelitian ini, kerapatan isi tanah pada irigasi 0,5 tertinggi terdapat pada perlakuan $\mathrm{G}_{1}$ dan sangat berbeda pada setiap perlakuan, sedangkan pada irigasi 0,75 kerapatan isi tidak berbeda jauh antar perlakuan namun kerapatan isi teringgi terdapat pada perlakuan $\mathrm{B}_{1}$ (Grafik 2). Porositas tanah tertinggi pada irigasi 0,5 terdapat perlakuan $\mathrm{B}_{0}$, sedangkan porositas terndah terdapat pada perlakuan $\mathrm{G}_{1}$. Pada irigasi 0,75 porositas tanah tertinggi terdapat pada perlakuan $\mathrm{B}_{0}$, namun hasil ini tidak berbeda jauh dengan perlakuan lainnya (Grafik 3).

Porositas tanah merupakan salah satu faktor yang mempengaruhi keadaan tanah termasuk perbedaan warna tanah. Tanah yang memiliki porositas tinggi cenderung mempunyai warna yang cerah dan terang dibandingkan dengan tanah yang mempunyai porositas kecil, selain itu, porositas juga berperan dalam pertukaran air serta udara di dalam tanah. Sedangkan kerapatan isi akan berbanding terbalik dengan presentase porositas tanah. Hal ini sesuai dengan pendapat Soepardi (1983) bahwa, kerapatan isi tanah berbanding terbalik dengan porositas. Jumlah ruang pori sangat ditentukan oleh presentase pasir, agregat tanah, dan kepadatan tanah (Buckman and Brady, 1982).

Porositas tanah didefinisikan sebagai persentase volume tanah yang ditempati oleh air dan udara (Buckman dan Brady, 1982). Udara dan air keluar masuk melewati ruang pori tersebut, sehingga semakin besar porositas tanah, maka tanah akan cepat menyerap air dan kemungkinan terjadinya genangan serta aliran permukaan yang membawa partikel tanah akan semakin kecil (Hillel, 1980).

Air tersedia biasanya dinyatakan sebagai air yang terikat antara kapasitas lapangan dan koefisien layu. Kadar air yang diperlukan untuk tanaman juga bergantung pada pertumbuhan tanaman dan beberapa bagian profil tanah yang dapat digunakan oleh akar tanaman. Tetapi untuk kebanyakan mendekati titik layunya, absorpsi air oleh tanaman kurang begitu cepat, dapat mempertahankan pertumbuhan tanaman, (Buckman and Brady, 1982). Berdasarkan pengamatan dan uji laboratorium pada penelitian ini persentase air tersedia untuk irigasi 0,5 dengan hasil tertinggi terletak pada perlakuan, perlakuan $B_{1}$ (bahan organik 5 ton/ha) yaitu $19,66 \%$ tertera pada (grafik 4), dan hasil terendah terdapat pada perlakuan $\mathrm{G}_{1}$ (gipsum $130 \mathrm{~kg} / \mathrm{ha}$ ) yaitu sebesar $6,53 \%$. Sedangkan pada irigasi 0,75 persentase air tersedia tertinggi terdapat pada perlakuan $\mathrm{B}_{1}$ (bahan organik 5 ton/ha) yaitu sebesar $12,48 \%$, dan hasil terendah terdapat pada perlakuan $\mathrm{B}_{0}$ (kontrol) yaitu sebesar $5,7 \%$.

\section{KESIMPULAN DAN SARAN}

\section{Kesimpulan}

Dari penelitian ini dapat disimpulkan :

1. Pemberian perlakuan bahan organik dan gipsum meningkatkan laju infiltrasi tanah. Laju infiltrasi paling cepat untuk irigasi 0,5 terdapat pada perlakuan $G_{1}$ (gipsum $130 \mathrm{~kg} / \mathrm{ha}$ ) dengan kecepatan laju infiltrasi konstan $168 \mathrm{~mm} / \mathrm{jam}$, sedangkan pada irigasi 0,75 terdapat pada perlakuan $\mathrm{B}_{1}$ (bahan organik 5 ton $/ \mathrm{ha}$ ) dengan kecepatan laju infiltrasi konstan $196 \mathrm{~mm} / \mathrm{jam}$.

2. Pemberian perlakuan bahan organik pada penelitian ini meningkatkan daya menahan air tanah pada semua perlakuan B1(bahan organik 5 ton/ha) dan B2 (bahan organik 10 ton/ha). Sedangkan pemberian perlakuan gipsum tidak berpengaruh terhadap daya menahan air tanah.

\section{Saran}

Perlu dilakukan penelitian lanjutan pada lahan yang sama 
untuk mengetahui apakah bahan organik mampu mempertahankan laju infiltrasi dan daya menahan air tanah untuk pertanian berkelanjutan.

\section{DAFTAR PUSTAKA}

Arsyad, S. 1989. Konservasi Tanah dan Air. Institut Pertanian Bogor Press. Bogor.

Buckman, H. O and N. C. Brady. 1982. Ilmu Tanah. Diterjemahkan oleh Soegiman. Bhatara Karya Aksara. Jakarta.788 hlm.

Hillel, D. 1980. Introducion to Soil Physics. Diterjemahkan oleh Rohiyanto, H. S. Dan Rahmad, H. P. Fakultas Pertanian Universitas Sriwijaya. Indralaya. $297 \mathrm{hlm}$.

Hoeft, B. 2001. Soil Fertility Management. Food Agriculture Organization, Rome.

Irwan, A. W. 2006. Budidaya Tanaman Kedelai (Glycine $\max ($ L.) Merill). Jurusan Budidaya Pertanian Fakultas Pertanian Universitas Padjadjaran. Jatinangor.

Khan, H. R., K. F. Yasmin, T. Adachi, and T. Ahmed. 1992. Effects of gypsum, Zn, and intermittent saline irrigation on the growth, yield, and nutrition of rice plants grown in a saline soil. Soil Science Plant Nutrition 3: 421-429.
Kurniawan, Harry., Ikaputra, dan Sandra Forestyana. (2014). Perancangan Aksesibilitas untuk Fasilitas Publik. Gadjah Mada University Press. Yogyakarta.

Nelson, P. N., A. R. Barzegar, and J. M. Oades. 1997. Sodicity and Clay Type:Influence on Decomposition of Added Organic. Matter Soil Sei. Soc. Am.J. 61:1052 -1057.

Subagyo, H. N., Suharta, dan A. B. Siswanto. 2000. Tanah- Tanah Pertanian di Indonesia hlm 2165 dalam Sumberdaya Lahan Indonesia dan Pengelolaannya Puslittanak. Bogor.

Subiksa, IGM. 2002. Pemanfaatan Mikoriza Untuk Penanggulangan Lahan Kritis. Makalah Falsafah Sains (PPs 702). Edisi April 2002. Program Pasca Sarjana. Institut Pertanian Bogor.

Subowo, J. Subaga, dan M. Sudjadi. 1990. Pengaruh bahan organik terhadap pencucian hara tanah Ultisol Rangkasbitung, Jawa Barat. Pemberitaan Penelitian Tanah dan Pupuk 9: $26 " 31$.

Utaya, S. 2008. Pengaruh Perubahan Penggunaan Lahan Perumahan Terhadap Sifat Biofisik Tanah dan Kapasitas Infiltrasi di Kota Malang. Jurnal. Universitas Negeri Malang. Malang. 